\title{
Geophagy in two parrot species in southern Pantanal, Brazil
}

\author{
Francisco Severo-Neto ${ }^{1,2}$ \\ ${ }^{1}$ Programa de Pós Graduação em Ecologia e Conservação, Centro de Ciências Biológicas e da Saúde - \\ CCBS, Universidade Federal de Mato Grosso do Sul-UFMS, CEP 79070-900, Campo Grande, MS, Brasil \\ ${ }^{2}$ Corresponding author: Francisco Severo-Neto, e-mail: netosevero@hotmail.com
}

SEVERO-NETO, F. Geophagy in two parrot species in southern Pantanal, Brazil. Biota Neotrop. 12(2): http:// www.biotaneotropica.org.br/v12n2/en/abstract?short-communication+bn00612022012

\begin{abstract}
Geophagy is a habit recorded for parrots, which seek earthy or soil-like substances presumably to help them in digestive functions, whether mechanical or chemical ones. Few studies are devoted to this feeding peculiarity in the Pantanal region. Here are reported two events of geophagy, for the Blue-and-yellow Macaw (Ara ararauna) and the Nanday Parakeet (Aratinga nenday) in the Pantanal subregions of the Miranda-Abobral and Nhecolândia, Mato Grosso do Sul, respectively.

Keywords: geophagy, Pantanal, psittacines, parrots, wetland, feeding ecology.
\end{abstract}

SEVERO-NETO, F. Geofagia em duas espécies de psitacídeos no Pantanal Sul, Brasil. Biota Neotrop. 12(2): http://www.biotaneotropica.org.br/v12n2/pt/abstract?short-communication+bn00612022012

Resumo: A geofagia é um hábito conhecido em psitacídeos, que se alimentam de terra ou argila supostamente por ajudar em funções digestivas, sejam mecânicas ou químicas. Poucos estudos são dedicados a essa peculiaridade alimentar na região do Pantanal. É feito aqui o registro de dois eventos de geofagia, para a arara-canindé (Ara ararauna) e o periquito-de-cabeça-preta (Aratinga nenday) nas sub-regiões pantaneiras da Nhecolândia e Miranda-Abobral, Mato Grosso do Sul, respectivamente.

Palavras-chave: geofagia, Pantanal, psittacidae, araras, área úmida, ecologia alimentar. 


\section{Introduction}

Geophagy, the consumption of earthy or soil-like substances such as clay, silt and sand, is a habit described for several animal taxa, especially herbivorous or strictly herbivorous species (Diamond et al. 1999). Among vertebrates, most studies on geophagy are on primates, as these mammals may ingest soil from anthills, termite mounds and nests of ovenbirds (Furnarius rufus) (Bicca-Marques \& Callegaro-Marques 1994, Krishnamani \& Mahaney 2000, Mahaney \& Krishnamani 2003, Sazima 2008).

The knowledge on geophagy among birds is scarce, and intensive studies on this issue are not frequent (Brightsmith 2004). Most of these studies were carried on with birds from the Peruvian Amazon, which use to cluster in flocks in hillsides with fragments of exposed soil, the so called clay licks (Burger \& Gochfeld 2003, Brightsmith 2004, Brightsmith \& Muñoz-Najar 2004). Geophagy is reported for Anseriformes, Columbiformes, Passeriformes, Casuariiformes, Galliformes and Psittaciformes (review in Brightsmith 2004). Among these orders, the greatest number of records is for the Psittaciformes, various species of macaws, parrots and parakeets (Mee et al. 2005, Symes et al. 2006, Lee et al. 2010).

The use of areas of moist and exposed soil is widespread among South America vertebrates and has been reported in Peru and some regions of Brazil (Vidolin et al. 2009, Tobler et al. 2009), including the Pantanal, where these clay mounds are popularly known as "barreiros". In the northeastern Pantanal, 14 species of vertebrates were recorded ingesting soil from "barreiros" (Coelho 2006). Some birds, including a Hyacinth Macaw (Anodorhynchus hyacinthynus (Latham, 1790)) and other parakeets, were also spotted ingesting soil; but not from the "barreiros" (Coelho 2006). This report is on geophagy among psittacines in the Pantanal wetlands, recording this behavior for the Blue-and-yellow Macaw, Ara ararauna (Linnaeus, 1758), and the Nanday Parakeet, Aratinga nenday (Vieillot, 1823), in two subregions of the Pantanal, Mato Grosso do Sul.

\section{Material and Methods}

The Pantanal is one of the largest continuous floodplain in the world; it is located in the Upper Paraguay Basin $\left(16-20^{\circ} \mathrm{S}\right.$ and $\left.55-58^{\circ} \mathrm{W}\right)$. This basin comprises about $496,000 \mathrm{~km}^{2}$ in which the Pantanal area is about $160.000 \mathrm{~km}^{2}$ distributed among Paraguay, Bolivia and Brazil; being $140,000 \mathrm{~km}^{2}$ in the Brazilian territory (Junk et al. 2006). Due to edaphic, hydrological and biogeographical variation, its ecosystem can be divided into 10 different sub-regions (Lourival et al 2000). Within these sub-regions, the observations on A. ararauna were made at Nhumirim Farm $\left(18^{\circ} 58^{\prime} \mathrm{S}\right.$ and $\left.56^{\circ} 38^{\prime} \mathrm{W}\right)$, located in the Nhecolândia sub-region and those on Aratinga nenday were made in the Miranda-Abobral sub-region, at the Base de Estudos do Pantanal $\left(19^{\circ} 34^{\prime} \mathrm{S}\right.$ and $\left.57^{\circ} 01^{\prime} \mathrm{W}\right)$, property of the Universidade Federal de Mato Grosso do Sul. Both geophagy events were reported trough casual observations.

\section{Results and Discussion}

The geophagic behaviour of A. ararauna was observed on 10 September 2010, at 8:30 AM The macaw was alone on the ground, at the edge of a "salina", term used for the characteristic ponds of the Nhecolândia sub-region. These ponds remain isolated from other ponds during the flood and thus have sandy soil and high concentrations of sodium and potassium (Sakamoto et al. 1996). The bird scraped the ground with the beak (Figure 1) and lifted the head, as it does while swallowing, doing this repeatedly. However, as I approached to take a photograph, about $100 \mathrm{~m}$ far from the bird, it flew. The wariness of parrots on the ground and their vulnerability

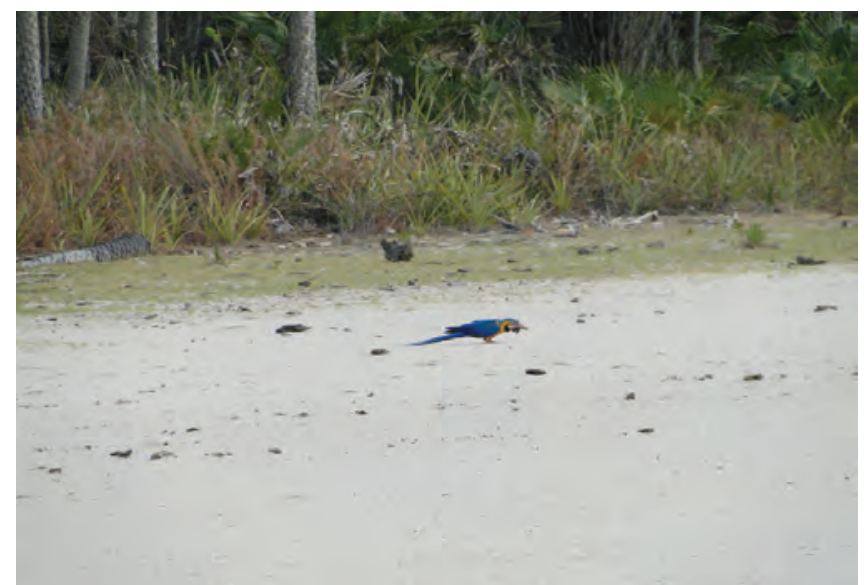

Figure 1. Blue-and-yellow Macaw (Ara ararauna) scraping earth (geophagy) at the edge of a "salina", a typical pond in the subregion of Nhecolândia, Mato Grosso do Sul, Brazil, in September 2010. Note mammal droppings (dark objects around the edge).

Figura 1. Arara-canindé (Ara ararauna) raspando terra (geofagia), na margem de uma salina, uma lagoa típica da sub-região da Nhecolândia, Mato Grosso do Sul, Brasil, em setembro de 2010. Note excrementos de mamíferos (objetos escuros ao redor da margem).

to predators during geophagy are discussed by Burger \& Gochfeld (2003).

Other vertebrates, such as tapirs (Tapirus terrestris) and peccaries (Pecari tajacu, Tayassu pecari and Sus scrofa) also visit the site to lick the soil. Faeces of these and other animals that visit the same spot are visible on Figure 1. Geophagy by Hyacinth macaws and parakeets was previously observed at this site (M. Tomas pers. comm.). Additionally, Ara ararauna was observed feeding of cattle feces (M. Tomas pers. comm.). Other bird species also found in the "salinas" in search of the "barreiros", include the Blue-throated Piping-Guan [Aburria cumanensis (Jacquin, 1784)], Bare-faced Curassow (Crax fasciolata Spix, 1825), Yellow-collared Macaw [Primolius auricollis (Cassin, 1853)], Blue-crowned Parakeet [Aratinga acuticaudata (Vieillot, 1818)] and the Monk Parakeet [Myiopsitta monachus (Boddaert, 1783)] (A.P. Nunes pers. comm.).

Aratinga nenday was observed scraping earth on 20 September 2010, at 5:30 PM Except for the work of Ragusa-Netto (2005), little is known on the biology of this species on Pantanal. The parakeet was alone on the ground, in a circle of naked soil (around $12 \mathrm{~m}^{2}$ ), repeatedly making movements of scraping and swallowing similar to those described above for A. ararauna (Figure 2). Nanday Parakeets are frequently found alone or in couple at this site, about $50 \mathrm{~m}$ far from the Miranda River, where there are some tree species used as perches (Mangifera indica, Cecropia pachystachya) or food (fruits of Attalea phalerata and flowers of Cocos nucifera) by these birds.

Several hypotheses are postulated to explain geophagy in birds. As a mechanical function, earthy grains would be responsible for crushing the food in the gizzard (Best \& Gionfriddo 1991). Biochemically, it is suggested that the ingested soil would help in the digestive processes buffering the gastric acids and providing mineral supplements. Other studies emphasize the importance of geophagy as a mean of adsorption for toxins and secondary compounds derived from the herbivorous diet and protection of gastrointestinal cells from these compounds (Gilardi et al. 1999). Diamond et al. (1999) argue that the diversity of parrots found in the western Amazon basin would be a reflection of geophagy, which allows these birds to consume a wider range of plants resources. 


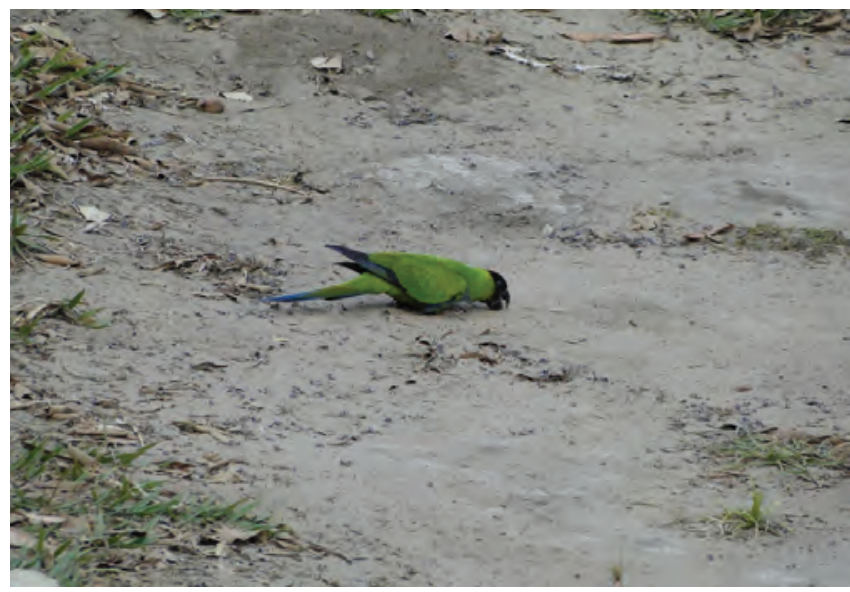

Figure 2. Nanday Parakeet (Aratinga nenday) scraping earth (geophagy) on a site of naked soil at the subregion in Pantanal known as Miranda-Abobral, in September 2010.

Figura 2. Periquito-de-cabeça-preta (Aratinga nenday) raspando terra (geofagia) em um local de solo nu na sub-região do Pantanal conhecido como Miranda-Abobral, em setembro de 2010.

\section{Acknowledgements}

I am grateful to Raul Costa Pereira for the discussions on geophagy, Alessandro Pacheco Nunes, Rudi Laps, and Marcelle Aiza Tomás for their assistance in drafting and reviewing this manuscript. I also thanks to Karla Campião for the English version of the text and to all involved in the Ecologia do Pantanal field course, class 2010, when the data was collected.

\section{References}

BEST, L.B. \& GIONFRIDDO, J.P. 1991. Characterization of grit use by cornfield birds. Wilson Bull. 103(1):68-82.

BICCA-MARQUES, J.C. \& CALEGARO-MARQUES, C. 1994. A case of geophagy in the black howling monkey Alouatta caraya. Neotrop. Primates. 2:7-9.

BRIGHTSMITH, D. 2004. Effects of Diet, Migration, and Breeding on Clay Lick Use by Parrots in Southeastern Peru. In American Federation of Aviculture Symposium. Brightsmith.

BRIGHTSMITH, D.J. \& MUÑOZ-NAJAR, R.A. 2004. Avian geophagy and soil characteristics in southeastern Peru. Biotropica. 36(4):534-543.

BURGER, J. \& GOCHFELD, M. 2003. Parrot behavior at a Rio Manu (Peru) clay lick: temporal patterns, associations, and antipredator responses. Acta Ethol. 6(1):23-34.

COELHO, I.P. 2006. Relações entre barreiros e a fauna de vertebrados no nordeste do Pantanal, Brasil. Dissertação de Mestrado, Universidade Federal do Rio Grande do Sul, Porto Alegre.
DIAMOND, J., BISHOP, K.D. \& GILARDI, J.D. 1999. Geophagy in New Guinea birds. Ibis141(2):181-193. http://dx.doi.org/10.1111/j.1474919X.1999.tb07540.x

GILARDI, J.D., DUFFEY, S.S., MUNN, C.A. \& TELL, L.A. 1999. Biochemical functions of geophagy in parrots: detoxification of dietary toxins and cytoprotective effects. J. Chem. Ecol. 25(4):897-922. http:// dx.doi.org/10.1023/A:1020857120217

JUNK, W.J., DA CUNHA, L.A., WANTZEN, K.M., PETERMANN, P., STRÜSSMANN, C., MARQUES, M.I. \& ADIS, J. 2006. Biodiversity and its conservation in the Pantanal of Mato Grosso, Brazil. Aquat. Sci. 68(3):278-309. http://dx.doi.org/10.1007/s00027-006-0851-4

KRISHNAMANI, R. \& MAHANEY, W.C. 2000. Geophagy among primates: adaptive significance and ecological consequences. Anim. Behav. 59(5):899-915. PMid:10860518. http://dx.doi.org/10.1006/ anbe.1999.1376

LOURIVAL, R., HARRIS, M. \& MONTAMBAULT, J.R. 2000. Introdução ao Pantanal, Mato Grosso do Sul, Brasil. In Uma avaliação Biológica dos Ecossistemas Aquáticos do Pantanal, Mato Grosso do Sul, Brasil (P.W. Willink, B. Chernoff, L. Alonso, J.R. Montambault \& R. Lourival). Conservation International, Washington.

LEE, A.T.K., KUMAR, S., BRIGHTSMITH, D.J. \& MARSDEN, S.J. 2010. Parrot claylick distribution in South America: do patterns of "where" help answer the question "why"? Ecography 33(3):503-513.

MAHANEY, W.C. \& KRISHNAMANI, R. 2003. Understanding geophagy in animals: standard procedures for sampling soils. J. Chem. Ecol. 29(7):1503-1523. PMid:12921433. http://dx.doi. org/10.1023/A:1024263627606

MEE, A., DENNY, R., FAIRCLOUGH, K., PULLAN, D.M. \& BOYDWALLIS, W. 2005. Observations of parrots at a geophagy site in Bolivia. Biota Neotrop. 5(2):321-324. http://www.biotaneotropica.org.br/v5n2/pt/ abstract?short-communication+bn02805022005

RAGUSA-NETTO, J. 2005. Extensive consumption of Tabebuia aurea (Manso) Benth. \& Hook. (Bignoniaceae) nectar by parrots in a tecoma savanna in the southern Pantanal (Brazil). Braz. J. Biol. 65(2):339-344. http://dx.doi.org/10.1590/S1519-69842005000200018

SAKAMOTO, A.Y., QUEIROZ NETO, J.P., FERNANDES, E. \& LUCATTI, H.M. 1996. Topografia de lagoas salinas e seus entorno no Pantanal da Nhecolândia/MS. In Simpósio Sobre Recursos Naturais e Sócio - Econômicos do Pantanal: Manejo e Conservação. EMBRAPA/ CPAP-UFMS, Corumbá.

SAZIMA, I. 2008. The parrotlet Forpus xanthopterygius scrapes at clay nests of the ovenbird Furnarius rufus: tasting or testing a new home? Rev. Bras. Ornitol. 16(3):256-269.

SYMES, C.T., HUGHES, J.C., MACK, A.L. \& MARSDEN, S.J. 2006. Geophagy in birds of Crater Mountain Wildlife Management Area, Papua New Guinea. J. Zool. 268(1):87-96. http://dx.doi.org/10.1111/j.14697998.2005.00002.x

TOBLER, M.W., CARRILLO-PERCASTEGUI, S.E. \& POWELL, G. 2009. Habitat use, activity patterns and use of mineral licks by five species of ungulate in south-eastern Peru. J. Trop. Ecol. 25(3):261-270. http://dx.doi. org/10.1017/S0266467409005896

VIDOLIN, G.P., BIONDI, D. \& WANDEMBRUCK, A. 2009. Seletividade de habitats pela anta (Tapirus terrestris) e pelo queixada (Tayassu pecari) na Floresta com Araucária. Sci. For. 37(84):447-458. 